\title{
I0
}

\section{O NEW WEIRD: HIBRIDISMO FORMAL E CONSCIÊNCIA POLÍTICA EM ESTAÇÃO PERDIDO, DE CHINA MIÉVILLE}

George Augusto do Amaral (USP)

Recebido em 04 nov 2019. George Augusto do Amaral é Mestre em Letras - Teoria Aprovado em 24 abr 2020.

Literária e Literatura Comparada pela Universidade de São Paulo. É membro do Conselho Editorial da Revista Fantástika 451. Pesquisa o estranhamento inerente às narrativas fantásticas pelo viés da psicanálise, teoria literária e teoria crítica. Lattes: http://lattes. cnpq.br/0859433264539531. Website: http://www. georgeamaral.com.br E-mail: georgeamaral@gmail.com.

Resumo: O objetivo deste artigo é contextualizar e discutir o New Weird, um subgênero da literatura fantástica surgido no fim do século $X X$, durante o momento em que a Grã-Bretanha passava pelo Science Fiction Boom, no qual a ficção científica, a fantasia e o horror sofreram uma retomada após um período de estagnação. A partir de um levantamento das principais definições a respeito do New Weird propostas por seus autores e da análise de sua obra mais relevante, Estação Perdido (2000), de China Miéville, pretendo comentar as influências e características fundamentais do subgênero. Defendo que os mundos ficcionais do New Weird, ainda que alternativos ao real, são construídos com detalhes que enfatizam relações sociais, políticas e econômicas que remetem à nossa realidade, o que possibilita conjecturas acerca do nosso próprio 
contexto histórico. Ao mesmo tempo, essas obras promovem uma diluição das fronteiras entre os gêneros da literatura fantástica, na medida em que características formais, convenções e temas tradicionais de ficção científica, fantasia e horror aparecem articuladas conjuntamente, de maneira a serem reiteradas, mas também renovadas.

Palavras-chave: Literatura; New Weird; Ficção científica; Fantasia; China Miéville; Science Fiction Boom.

Abstract: The purpose of this paper is to contextualize and discuss the New Weird, a subgenre of the fantastic literature that emerged in the late twentieth century, during the Science Fiction Boom in Britain, a moment when science fiction, fantasy and horror suffered a resumption after a period of stagnation. Based on several definitions proposed by New Weird writers and on the criticism of its most relevant novel, China Miéville's Perdido Street Station (2000), my intention is to comment on its influences and main literary properties. I argue that the fictional worlds of the New Weird, albeit alternative to the real, are constructed with details that emphasize social, political and economic relations which make reference to our reality, thus enabling conjectures on our own historical context. At the same time, this type of fiction promotes a blurring of the boundaries between the genres of the fantastic literature, as long as formal structure, tropes and traditional themes of science fiction, fantasy, and horror are jointed together, being reaffirmed bur also renewed. Keywords: Literature; New Weird; Science fiction; Fantasy; China Miéville; Science fiction boom.

No Reino Unido, o Science Fiction Boom começou no fim dos anos 1990, quando houve um aumento significativo na quantidade de obras de literatura fantástica ${ }^{1}$ publicadas, assim

1 Utilizo no âmbito deste estudo o termo "literatura fantástica" para designar o conjunto 
como uma melhora na sua qualidade estética, o que resultou também em uma expansão mercadológica. Novos autores que ganharam destaque, como China Miéville, Alastair Reynolds e Steph Swainston, enquanto outros já consagrados, como M. John Harrison, colaboraram para uma renovação dos gêneros. Revistas literárias especializadas ressurgiram e se multiplicaram, propiciando espaço para divulgação de contos, entrevistas e críticas. Um exemplo foi a The 3rd alternative, dedicada especialmente a narrativas que não se limitassem a trabalhar apenas um gênero.

Quase simultaneamente, porém em escala global, houve uma expansão mais específica das histórias de fantasia, com a publicação de séries de múltiplos volumes como Harry Potter (1997-2007), de J. K. Rowling, As crônicas de gelo e fogo, de George Martin (1996-), His Dark Materials (1995-2000), de Philip Pullman, e também por uma renovação do público de 0 senhor dos anéis (1954-55), graças ao lançamento da produção cinematográfica de mesmo nome dirigida por Peter Jackson (2001-2003). Segundo Fredric Jameson (2005, p.57), a difusão global da fantasia nesse período foi ainda maior do que a da ficção científica, especialmente em termos de público e da formação de comunidades de fãs, o que não refletia necessariamente aspectos qualitativos de uma ou outra obra, mas colaborou para a aceitação e o crescimento do mercado da literatura fantástica como um todo.

das obras dos gêneros da fantasia, ficção científica e horror, e seus diversos subgêneros. Não existe ainda um consenso entre críticos para designar o agrupamento desses gêneros, sendo comum a ocorrência de nomes como literatura insólita, literatura de gênero, ficção especulativa, literatura do fantástico, ficção imaginativa e simplesmente fantasia ou fantástico. 
Similarmente, mas em menor escala, o gênero horror também se revitalizou, principalmente com o resgate de temáticas e formas tradicionais do gótico, com autores como Alan Moore, Kim Newman e Neil Gaiman, este último apontado muitas vezes, ao lado de Miéville, como um dos principais escritores do Boom (BROOKER, 2009, p.263).

Foi nesse ambiente de grande efervescência que surgiu o New Weird, um subgênero ou movimento que logo ganhou notoriedade por destacar-se do restante do Boom graças às suas características muito particulares, as quais rompem com muitas das convenções dos gêneros do fantástico.

Neste estudo pretendo contextualizar historicamente o New Weird e levantar suas principais definições e inspirações, além de abordar em detalhe duas de suas características principais: a criação de mundos alternativos dotados de forte consciência política e social e a hibridização das convenções dos gêneros da literatura fantástica. O romance Estação Perdido (2000), de China Miéville, obra mais representativa do subgênero, servirá como base principal de análise.

\section{O NEW WEIRD}

O nome New Weird foi atribuído por M. J. Harrison e China Miéville a determinadas obras do fim do século $X X$ e início do $X X I$, as quais ambos consideravam muito diferentes do que fora produzido até então. Para eles, os autores dessas histórias deveriam se posicionar e se autonomear enquanto movimento ou subgênero antes que o mercado se adiantasse e o fizesse segundo suas próprias prerrogativas. 
Foi com essa intenção que Harrison publicou em uma página de discussões online, em abril de 2003: "O New Weird. Quem faz isso? O que é isso? É mesmo alguma coisa? É mesmo novo?" (TNW², 2003, tradução nossa). Esse questionamento deu início a um debate que durou vários meses e envolveu escritores, editores e críticos especializados em ficção científica, fantasia e horror. Além de Harrison, diversos autores de obras consideradas New Weird também participaram, como China Miéville, Steph Swainston, Alastair Reynolds, Justina Robson, Jeff VanderMeer, Jeffrey Ford, entre outros. A pertinência de se criar ou não uma categoria ou etiqueta para esse tipo de ficção e as vantagens e desvantagens que isso traria para autores, público e mercado foram alguns dos assuntos mais debatidos, assim como as características formais e temáticas das obras.

Em julho de 2003, Miéville publicou um editorial na revista de ficção científica The 3rd Alternative, intitulado "Long live the New Weird", no qual define o que significa, para ele, esse termo. O autor diz que "alguma coisa está acontecendo na literatura do fantástico", cita a discussão online e conclui como se respondesse às dúvidas remanescentes sobre a pertinência da nomeação: "Então, qual é a questão? Por que chamar isso de New Weird? Porque alguma coisa está acontecendo. E isso merece ser marcado, nomeado e entendido" (MIÉVILLE, 2003, p.1, tradução nossa).

A partir de então, o termo New Weird passou a ser amplamente aceito para designar esse subgênero da literatura fantástica. Como 2 A frase de Michael John Harrison foi publicada em uma página de discussão online (message board) da TTA Press, hoje desativada, porém mantida como arquivo na página eletrônica pessoal da autora Kathryn Cramer. In http://www.kathryncramer.com/ kathryn_cramer/the-new-weird-p-1.html. Acesso em Mai.2017. As referências a esses arquivos serão expressas no texto como "TNW, 2003". 
ressalta Jeff VanderMeer (2008, p.xiii), por volta de 2005, o termo já era usado com regularidade por leitores, escritores e críticos, ainda que houvesse muita dissonância entre o significado que cada um atribuía ao New Weird.

\section{DEFINIÇÕES}

Ao longo da extensa discussão online proposta por Harrison é possível identificar algumas falas que melhor abordam os pressupostos de forma e conteúdo que os autores consideravam característicos do New Weird. Uma das mais extensas definições foi elaborada por Steph Swainston, que viria a publicar no ano seguinte seu romance de estreia, The Year of Our War (2004) e passar a fazer efetivamente parte do New Weird:

O New Weird é um desenvolvimento maravilhoso em ficção literária fantástica. Eu o teria chamado de Fantasia Radiante, porque ele é vívido e porque é talentoso. O New Weird é uma reação contra a fantasia heroica saturada que tem sido a única disponível por tempo demais. Em vez de ser derivado de Tolkien, ele é influenciado por Gormenghast e Viriconium. É incrivelmente eclético e tira ideias de qualquer fonte. Bebe da mitologia dos índios americanos e das culturas orientais em vez das tradições europeias e nórdicas, mas sua maior influência é a cultura moderna - cultura das ruas - mesclada com as mitologias antigas. O texto não é experimental, mas as criaturas são. Ele é incrivelmente empático. [...] Filmes são uma fonte de inspiração porque a ação é vital. Os elfos foram os primeiros colocados contra a parede quando a revolução chegou, e no lugar deles queremos a vastidão do universo dos filmes de ficção científica 
colocada na página. Há muita mistura de gêneros acontecendo, graças a Deus. [...] O New Weird agarra de tudo e, por isso, a mistura de gêneros é parte dele, mas não o principal. O New Weird é secular e muito consciente politicamente. Questões de moralidade são postas em evidência. Mesmo a política, contudo, é secundária em relação ao tema principal deste subgênero: o detalhe. Os detalhes são brilhantes, alucinantes, cuidadosamente descritos. [...] O New Weird tenta colocar o leitor em um mundo que ele não espera, um mundo que o surpreende - o leitor olha em volta e vê um mundo ganhar vida por meio dos detalhes. Esses detalhes - vestimentas, comportamento, escamas e dentes - são o que faz os mundos do New Weird tão parecidos com o nosso, por serem tão reconhecíveis e bem descritos. (TNW, 2003, tradução nossa)

Outros autores tentaram listar as características constituintes do New Weird em diversos comentários publicados ao longo de todo período em que o fórum de discussão permaneceu no ar. Cito aqui apenas alguns mais representativos ou que sumarizam pontos discutidos:

M. John Harrison:

[O New Weird] faz precisa alusão aos Weird Tales e especialmente ao fato de que, naquela época maravilhosa e não corrompida do mundo, tudo ainda podia ser misturado - horror, ficção científica e fantasia - e ninguém te olharia torto ou diria que sua carreira estava acabada se você continuasse fazendo isso. [...]

Percebo cada vez mais que tanto o New Weird quanto o New Space Opera, apesar de cada um ter suas raízes bem definidas, são uma resposta para o agora, mais do que um tipo de desenvolvimento 
dentro da história do gênero em si mesmo, ou até do que uma raiz alternativa, mas ainda assim histórica. Esses escritores estão escrevendo sobre o mundo hoje.

Cheryl Morgan:

Como você [VanderMeer] eu refleti sobre o China [Miéville], porque Bas-Lag ${ }^{3}$ é um mundo muito diferente e muitas vezes bastante bizarro. [...] A ambientação pode ser ímpar, mas Yagharek e Bellis Coldwine ${ }^{4}$ são pessoas reais com emoções reais com quem nós podemos nos identificar até certo ponto. Muitas obras de ficção científica e fantasia são mais sobre o mundo do que sobre os personagens que o habitam, e por isso são acessíveis apenas para pessoas que ficam confortáveis com mundos alternativos estranhos.

Jeff Ford:

Esses dois livros [Estação Perdido e The scar] são verdadeiros épicos. São altamente cinematográficos (eu quero dizer em relação ao olho interno do leitor) e um rico e recompensador banquete de personagens e conceitos, enquanto que livros relativamente recentes que prometiam esse escopo não cumpriram com as expectativas. O que ele [China Miéville] tem que atrai leitores é um poder de visão abrangente e obstinado. Essa energia excita os leitores.

\section{John Harrison:}

Dois componentes do Novo [New], para mim, são: a) o transbordamento da realidade e das experiências pessoais; e b) a política. Nem um nem outro são novos no sentido de aparecerem pela primeira vez na ficção científica ou na fantasia;

3 Bas-Lag é o nome do mundo ficcional onde se passam os romances Estação Perdido (2000), The scar (2002) e The iron council (2004), de China Miéville.

4 Yagharek e Bellis Coldwine são personagens dos romances de Miéville. 
ambos são novos no sentido em que refletem a visão de mundo de uma nova geração. (TNW, 2003, tradução nossa)

Pouco depois, no editorial para a revista The 3rd Alternative, Miéville também define o New Weird. Ele propõe sua visão das características do subgênero:

Escrevemos livros que alegremente ignoram as fronteiras entre ficção científica, fantasia e horror. [...]

O New Weird, na sua tentativa de amorosamente inverter, subverter, reverter e converter os clichês do fantástico, é tanto uma renúncia quanto um retorno. A fantasia banal é uma traição ao próprio aspecto fantástico que ela tenta representar, e é porque o New Weird se rende a esse fantástico que ele o resgata de si mesmo.

O New Weird é secular e político, como Steph Swainston apontou. Não importa o que o escritor pense a respeito, a ficção em si reage contra o moralismo religioso e o misticismo consolador. É uma bagunça. Parece real, não como um conto de fadas. É uma literatura que sabe que o mundo e a literatura inserida nele são politicamente construídos. Para o New Weird, moralidade é um problema, não uma solução ou condição básica, e a política é inevitável. [...] Essa é a ficção pós-Seattle. E, mais importante, é uma ficção que confia no leitor e, portanto, rende-se ao estranhamento [Weird]. Não é pós-moderna nem busca romper com a quarta parede. [...]

Não é ficção "utópica" ou "distópica" ou "metafórica", que faz do estranhamento um dedo que aponta para os problemas. Embora, é claro, saiba que há problemas a serem apontados. O New Weird atua nas duas frentes. Confia no leitor - sabe que a mente humana é uma máquina para 
processar metáforas, e que o Weird pode ser celebrado por si mesmo, e ainda ser, também, mais do que isso. (MIÉVILLE, 2003, p.3, tradução nossa)

Jeff VanderMeer, por sua vez, na coletânea de contos e artigos The New Weird (2008), que organizou junto de sua esposa, Ann VanderMeer, propôs uma nova definição:

O New Weird é um tipo de ficção urbana passada em mundos alternativos que subverte as ideias de ambientação derivadas do Romantismo comuns à fantasia tradicional, optando por modelos complexos com base no mundo real como ponto de partida para a criação de cenários que combinam tanto elementos da ficção científica quanto da fantasia. O New Weird tem uma característica visceral, atenta a cada momento, e usa com frequência elementos de horror surreal ou transgressivo para criar tom, estilo e efeitos. [...] A ficção New Weird é muito consciente do mundo moderno, mesmo que disfarçadamente, mas nem sempre é abertamente política. Como parte dessa percepção do mundo moderno, o New Weird conta com seu poder visionário para uma "rendição ao estranho" que não está, por exemplo, hermeticamente fechado em uma casa assombrada ou em uma caverna na Antártida. A "rendição" (ou "crença") do escritor pode adotar muitas formas, algumas delas envolvendo até o uso de técnicas pós-modernas que não comprometem a superfície de realidade do texto. (VANDERMEER, 2008, p.xvi, tradução nossa)

A definição de VanderMeer é a mais recente e também mais ampla, possivelmente refletindo que o subgênero perdeu especificidade ao longo dos anos. De fato, a lista de obras que VanderMeer (2008, p.405) classifica como New Weird ou como 
estímulos anteriores ocupa quatro páginas, expandindo em muito o leque de autores inicialmente considerados como seus integrantes.

A partir desse levantamento da discussão a respeito do New Weird, é possível analisar com maior detalhe alguns de seus aspectos que aparecem nas definições de cada autor.

\section{INFLUÊNCIAS}

Uma das características do New Weird mais ressaltadas é a forma com que essa ficção mescla as convenções tradicionais da ficção científica, da fantasia e do horror, ao mesmo tempo em que as renova e as reforça. Ou seja, trata-se tanto de uma renúncia quanto de um retorno, como afirma Miéville (2003, p.3). No entanto, é uma renúncia que não se propõe a negar ou superar a tradição desses gêneros, e tampouco transcender o nicho e se aproximar a outras literaturas, criando obras que se afastem da literatura fantástica. Busca-se, na verdade, enfatizar as características dessa ficção, trabalhando com elas de maneira interligada e, como diz Harrison, resgatar o tempo maravilhoso dos Weird Tales, quando ainda não havia distinção mercadológica entre os três gêneros (TNW, 2003). Assim, a hibridização formal do New Weird é tanto uma inovação quanto o resgate de um momento anterior.

Esse período invocado por Harrison, a época dos Weird Tales, abrange o fim do século XIX e início do XX, quando autores como H.P. Lovecraft, Robert Chambers e Arthur Machen deram vida ao Weird hoje chamado de "tradicional". O horror era o aspecto central dessas narrativas, mas elas já apresentavam características que, mais tarde, seriam consideradas típicas da 
fantasia e da ficção científica. Essa mescla fica ainda mais clara pela forma com que as obras chegavam ao público, por meio das primeiras revistas Pulp, como a Weird Tales Magazine, que se tornou símbolo dessa época e deu nome ao tipo de ficção. Os contos Weird eram publicados ao lado de histórias de cunho científico, como as escritas por Isaac Asimov, e também de fantasias heroicas, como as aventuras de Conan, Zorro e Tarzan.

Naquele momento as definições dos gêneros da literatura fantástica ainda não haviam se estabelecido; foi apenas a partir do final da década de 1920 que o mercado editorial passou a defender essas categorizações e as revistas se subdividiram de acordo com cada nicho. Além disso, os autores da época recebiam pagamentos pelos contos publicados, o que os levava a trabalhar sob encomenda ou a escrever com as preferências de determinada revista em mente, o que colaborou para distanciar os gêneros, criar uma gama de narrativas muito parecidas entre si e consolidar o caráter comercial que a literatura fantástica de certa forma possui até hoje.

H.P. Lovecraft pode ser considerado a principal influência dessa época para o New Weird, pois apresenta em sua cosmologia própria a atmosfera do horror cósmico, repleta de monstros fantásticos explicados por um viés científico: seres antigos vindos do espaço, adormecidos em ilhas submersas onde eram adorados como deuses por religiões antigas e descobertos por viagens de exploração arqueológica. Uma de suas mais conhecidas criações, o Cthulhu, é descrito como

um monstro de traços vagamente antropoides, mas com uma cabeça de polvo cujo rosto era um 
amontoado de tentáculos, um corpo escamoso, prodigiosas garras nas patas dianteiras e traseiras e longas asas estreitas nas costas". (LOVECRAFT, 2012, p.107)

Miéville considera essa descrição como o melhor exemplo de ficção Weird, pois demonstra a maneira revolucionária com que tanto Lovecraft quanto os outros autores da época passaram a criar monstros, evitando as figuras tradicionais da mitologia e do gótico. Para Miéville, essa nova forma de representar monstruosidades está relacionada com uma crise da época, marcada pela Primeira Guerra Mundial:

Os monstros que habitam esses contos representam um rompimento radical com qualquer tradição folclórica. Em vez de lobisomens, vampiros ou fantasmas, os monstros de Lovecraft são aglomerações de bolhas, barris, cones e cadáveres, costurados a partir de cefalópodes, insetos, crustáceos ou outros animais, e que se destacam justamente por não fazerem parte do leque de monstruosidades da tradição ocidental. [...] No fim do século XIX e início do XX, os grandes escritores da ficção Weird estão respondendo ao começo de um período de crise da modernidade capitalista, no qual as soluções grosseiras da racionalidade burguesa progressiva se estilhaçaram. No coração desta crise está a Primeira Guerra Mundial, quando a carnificina em massa perpetrada pelas nações mais modernas fez com que as reinvindicações por um sistema moderno "racional" se tornassem uma piada de mau gosto. O fantástico sempre foi indispensável para pensar e repensar a sociedade, mas com a guerra moderna os monstros tradicionais haviam se tornado profundamente inadequados e subitamente nostálgicos. [...] Esse horror sublime 
renovado é investigado por cientistas, doutores, engenheiros [...], e é a sua própria "racionalidade" que desperta o monstro radical e incrível. (MIÉVILLE, 2009, p.512-513, tradução nossa)

O New Weird resgata essa estética de monstros disformes, cuja aparência é de difícil compreensão para aqueles que os observam. São repletos de tentáculos, membranas e carapaças que interagem de maneira ilógica, sempre com aspecto viscoso e assustador. E, literalmente, olhar para essas criaturas diretamente significa, muitas vezes, sujeitar-se à loucura, no caso de Lovecraft, ou à dominação, em Miéville. Em Estação Perdido, o melhor exemplo dessa estética aparece na caracterização das criaturas chamadas de mariposas-libadoras:

Algo negro se ergueu do piso no topo da escadaria. [...]

A coisa se desdobrou. A sensação era de florescimento. De expansão após o cativeiro, como um homem ou uma mulher que abrisse os braços após sair da posição fetal. Mas multiplicada e ampliada. Como se os membros indistintos da coisa pudessem se dobrar mil vezes, de modo que ela se desfraldasse como uma escultura de papel, erguendo e estendendo braços, pernas, tentáculos ou caudas que se abriam e continuavam a se abrir. A coisa que estivera sentada como um cão se ergueu e se abriu, e tinha quase o tamanho de um homem. [...]

Olhos que não eram olhos. Dobras, arestas e curvas orgânicas, como caudas de rato que tremessem e se contraíssem ao morrer. E aqueles estilhaços de ossos descoloridos, tão longos como dedos, que brilhavam de alvor e se abriam e salivavam e eram dentes... [...] 
Quatro foles sussurrantes de matéria negra sobre as costas da criatura saltaram para fora, e para fora de novo, e outra vez, encaixando-se em posição, tremulando e expandindo-se em vastas dobras de carne espessa e sarapintada, até um tamanho impossível: uma explosão de padrões orgânicos, uma bandeira desfraldada, punhos cerrados se abrindo. [...]

Lublamai girou sobre os calcanhares para encarála, olhou diretamente para as cores mutantes, o espetáculo obscuro e vívido...

...e então já não pensava em gritar, só em observar as marcas que giravam e se derramavam pelas asas, em perfeita simetria, como nuvens no céu noturno acima e na água abaixo. (MIÉVILLE, 2016, p.224-225)

Após o período de incubação em uma crisálida multicolorida, como mariposas normais, as mariposas-libadoras rompem esse invólucro e, em minutos, já são caçadoras praticamente perfeitas, capazes de ameaçar a existência de toda a vida inteligente da cidade de New Crobuzon. Apesar de não serem divindades, como o Cthulhu de Lovecraft, há certa similaridade em suas origens ficcionais, pois são criaturas vindas de uma terra distante, onde uma fratura no planeta permitiu que seres das profundezas escapassem para a superfície. Os deuses do Weird tradicional também costumam habitar o subterrâneo ou o fundo do mar, esperando para serem despertos por algum evento ou pela interferência humana.

Apesar da originalidade em relação às mariposas-libadoras, diferentemente dos autores do Weird tradicional, Miéville não abandona totalmente os seres fantásticos da tradição europeia, como os vampiros, e ainda adiciona ao romance referências a 
mitos de culturas pouco exploradas na fantasia literária. No mundo ficcional de Bas-Lag há, por exemplo, os homens-pássaro garudas, inspirados pela mitologia hindu; os anfíbios vodyanoi, cuja origem está nas lendas eslavas; e os khepri, baseados na deusa egípcia de mesmo nome, cuja cabeça é um escaravelho:

A luz refletia nos olhos multifacetados de Lin. Suas pernas-cabeça estremeceram. Ela pegou metade de um tomate e o agarrou com as mandíbulas. Abaixou as mãos enquanto as partes internas de sua boca futucavam a comida que seu maxilar externo mantinha firme.

Isaac observava o imenso escaravelho iridescente que era a cabeça de sua amante enquanto ela devorava seu café da manhã.

Ele a observou engolir, viu sua garganta subir e descer onde a pálida barriga insetoide se transformava suavemente em pescoço humano... não que ela houvesse aceitado essa descrição. Humanos têm corpos, pernas e mãos de khepri; e cabeça de gibão pelado, dissera ela um dia.

Ele sorriu e pendurou o pedaço de porco frito à sua frente, enrolando a língua ao redor dele, enxugando os dedos engordurados na mesa. Sorriu para ela. Ela ondulou as patas da cabeça para ele e fez um sinal: Meu monstro. (MIÉVILLE, 2016, p.24)

Defendo, porém, que a incorporação dessas criaturas mitológicas ao romance acontece de maneira subvertida, pois, na maioria das vezes, apenas os seus nomes e sua aparência remetem às lendas originais; outras características são desconsideradas. As khepri exemplificam essa estética uma vez que, diferentemente do deus egípcio masculino, têm a parte humana de seus corpos sempre feminina e não possuem poder divino ou mesmo qualquer 
relação com o culto ao sol, o que as afasta do mito original. Além disso, Miéville cria todo o contexto de existência dessa raça, detalhando desde a forma com que as khepri se alimentam, como funciona sua cabeça-besouro, as propriedades sexuais de suas asas delicadas, sua linguagem baseada em borrifos químicos, a relação entre machos que são apenas insetos e as fêmeas híbridas, até a origem desse povo em uma terra distante, sua imigração e formação de guetos na cidade de New Crobuzon. Portanto, da origem egípcia, os khepri de Miéville só mantiveram o nome e a cabeça de escaravelho.

\section{CONSCIÊNCIA POLÍTICA}

Toda essa preocupação com a complexidade da ambientação e extensão dos detalhes demonstrada em relação às khepri reitera a definição de New Weird de Swainston e se articula com o que Miéville (2003, p.3) e VanderMeer (2008, p.xvi) chamam de "renderse ao estranhamento". Trata-se de criar e organizar o cenário fantástico extensivamente de acordo com sua lógica interna, sem deixar de buscar conexões com o mundo real, mas não submetendo necessariamente todos os aspectos da obra a essa relação metafórica. Miéville critica a ficção científica ou a fantasia cujo único objetivo seja retratar a realidade por meio de artifícios fantásticos, como se fosse uma alegoria. Para o autor, é preciso admitir que a obra serve também ao entretenimento e que a imersão do leitor em um mundo estranho complexo e coerente, segundo suas lógicas internas, faz parte de se permitir render-se ao impossível:

Eles pensam que a ficção científica é sobre analogias, metáforas e assim por diante. Eu 
refuto isso. Acredito que esses são componentes inevitáveis, mas é o render-se ao impossível, ao estranhamento, que caracteriza o gênero. Aqueles que apenas flertam com a ficção científica não se rendem a ela; se distanciam dela e colocam um subtexto em neon dizendo: "tudo bem, isto não é realmente sobre naves espaciais e alienígenas, é sobre a vida real". Não entendem que a ficção científica pode ser sobre as duas coisas, e que fariam a segunda melhor se escrevessem seriamente sobre as primeiras. (GORDON e MIÉVILLE, 2003, p.366, tradução nossa)

Essa perspectiva de não restringir as particularidades fantásticas da obra possibilita que a ambientação ganhe complexidade, sendo possível ao leitor desfrutar mais intensamente da aventura narrada e até, se quiser, ignorar as relações que existem entre ficção e realidade. Por outro lado, como ressalta Miéville, essa riqueza de detalhes favorece inclusive que as relações com o mundo real sejam mais fortes e impactantes. De fato, a importância como crítica social do New Weird é citada em todas as definições, ressaltando que se trata de uma ficção consciente das contradições históricas e sociais da época em que os romances foram escritos e que não tenta se afastar dessas questões, mas incorporá-las, criando cenários ficcionais baseados em "modelos complexos do mundo real", como afirma VanderMeer (2008, p. xvi), e que dizem respeito ao "agora", conforme comenta Harrison (TNW, 2003).

Citado também como ficção "pós-Seattle", em referência às manifestações populares contra a Organização Mundial do Comércio em 2000, o New Weird está relacionado à percepção de 
que existem processos políticos e econômicos globais que precisam ser questionados, mas também ao retorno de uma esperança de transformação que havia desaparecido da literatura fantástica britânica dos anos anteriores, período que Miéville considera como uma fase de pessimismo e melancolia:

As ruínas ainda estão lá, mas eu acredito que há mais dinamismo em relação ao ambiente. [...] O que aconteceu recentemente foi que, na minha opinião, ainda temos sobretudo a mesma agenda agressiva, neoliberal, voltada ao lucro e anti-humanitária, mas tem crescido um sentimento incrivelmente excitante de que há alternativas (os protestos contra a Organização Mundial do Comércio em Seattle no ano 2000 foram um divisor de águas), as quais não existiam nos anos 1980 e nem mesmo durante a década de 1990. No meio cultural, isso não se traduz em uma ficção científica obviamente política ou otimista, mas coloca nela um potente sentido de intervenção social e de interação tanto com as paisagens reais quanto ficcionais. (GORDON e MIÉVILLE, 2003, p.362, tradução nossa)

Nesse sentido, Fredric Jameson comenta que a nova geração da esquerda pós-globalização se aproximou mais uma vez do slogan da utopia, após o gênero ter passado décadas em desuso. Isso se deu devido ao descrédito dos partidos comunistas depois do colapso dos países socialistas e ao crescente ceticismo em relação a concepções tradicionais de revolução. Ou seja, a "consolidação do mercado mundial emergente - pois isto é o que está em questão na tão comentada globalização - pode eventualmente permitir que novas formas de intervenção política e social se desenvolvam" (JAMESON, 2005, p.xii, tradução nossa), o que também levará a 
uma busca por novos sistemas de governo apesar da concepção generalizada de que não há alternativas para o capitalismo.

O que é incapacitante não é a presença de um inimigo, mas a crença universal, não apenas de que essa tendência é irreversível, mas de que as alternativas históricas ao capitalismo se mostraram inviáveis e impossíveis, e de que nenhum outro sistema socioeconômico é concebível, e nem mesmo disponível na prática. Os utópicos não apenas se oferecem para conceber tais sistemas alternativos; a forma utópica é ela mesma uma meditação representacional sobre a diferença radical, a alteridade radical e a natureza sistêmica da totalidade social. (JAMESON, 2005, p.xii, tradução nossa)

As afirmações de Jameson e Miéville, colocadas em perspectiva, possibilitam a defesa de que o New Weird, no que diz respeito às características políticas e sociais presentes nas obras, aproxima-se do gênero da utopia, mais especificamente das distopias críticas, as quais, segundo Tom Moylan, são formas típicas da virada do século, que se baseiam no sistema corrente e oferecem

não apenas críticas astutas a respeito da ordem das coisas, mas também explorações dos espaços e possibilidades de oposição dos quais a próxima rodada de ativismo político pode obter sustentação e inspiração imaginativas. (MOYLAN, 2000, p.xv, tradução nossa)

Apesar de Miéville, no editorial para a The 3rd Alternative, defender que o New Weird não é utópico ou distópico, pois não foca em apontar os problemas da realidade, ele mesmo afirma, na 
sequência, que há de fato problemas a serem apontados, e que o New Weird atua das duas formas, ou seja, tanto mostrando questões reais quanto possibilitando uma imersão em um mundo fantástico que tem vida própria e não depende das metáforas para ser rico e interessante, justamente um dos aspectos da distopia crítica.

\section{HIBRIDISMO DOS GÊNEROS}

A maneira com que fantasia, ficção científica e horror se mesclam no New Weird é a última de suas características principais que gostaria de discutir neste estudo. Para tanto, podemos mais uma vez tomar como exemplo Estação Perdido. O romance de Miéville tem como cenário o mundo de Bas-Lag, um planeta sem nenhuma relação direta com a Terra; não há menção de sua existência nem mesmo em lugares distantes da galáxia, como acontece em muitas histórias de viagens espaciais ou explorações planetárias, como $A$ mão esquerda da escuridão (1969), de Ursula Le Guin. Em Bas-Lag, continentes, raças, deuses, idiomas, cidades e países são muito diferentes da nossa realidade; até certas leis da natureza funcionam de forma específica, graças à presença da magia (chamada de taumaturgia) que permeia e interfere em diversas atividades da população. Por outro lado, como discutimos acima, mesmo nesse cenário alternativo ainda é possível identificar a presença de relações sócio-políticas que remetem ao mundo real.

No começo da narrativa, o protagonista Isaac acorda de um sonho:

Isaac Dan der Grimnebulin havia acabado de perceber que estava sonhando. Ficara terrivelmente incomodado ao se encontrar mais uma vez trabalhando na universidade, desfilando 
em frente a um enorme quadro-negro coberto por representações vagas de alavancas, forças e tensões. Introdução à ciência dos materiais. Isaac já estava havia algum tempo encarando a classe ansioso quando aquele desgraçado ensebado do Vermishank enfiara a cabeça para dentro da sala. (MIÉVILLE, 2016, p.22)

Isaac sonha que está empregado mais uma vez na universidade, defronte a uma lousa, portanto deduz-se que o personagem é ou já foi um professor de uma disciplina de exatas, chamada de "Introdução às Ciências Materiais", relacionada a "alavancas, forças e tensões". Aparece aqui, assim, um dos maiores topoi da ficção científica, desde Mary Shelley a Júlio Verne e H.G. Wells: o herói cientista. A respeito disso, Darko Suvin comenta:

A ciência é o verdadeiro mestre demoníaco de todos os aprendizes de feiticeiros de Wells, que - como Frankenstein ou certos personagens de contos folclóricos - revelaram e libertaram poderes e monstros destrutivos. Desde o viajante do tempo, passando por Moreau e Griffin, até Cavor, o personagem principal da sua ficção científica é o cientista-aventureiro como pesquisador do Novo, que desconsidera o bom senso e as opiniões alheias. Embora poderosa, uma vez que traz o futuro, a ciência é um mestre difícil. Como Moreau, é indiferente ao sofrimento humano; como os marcianos, explode as pretensões otimistas do século XIX, liberais ou socialistas, de controlá-la sobre o universo. (SUVIN, 1979, p.210, tradução nossa)

O herói de Miéville encarna muitos desses aspectos descritos por Suvin em relação aos personagens de Wells. Isaac é um cientista brilhante, mas indisciplinado e mau professor, o que o obrigou a 
aceitar um contrato como pesquisador-freelancer, tornando-se um renegado da universidade. Sua pesquisa, pouco convencional, não se encaixa em nenhuma das categorias teóricas; trata-se de uma busca por algo novo, o que também o tornou famoso por ser capaz de resolver questões científicas únicas:

Naqueles tempos, seu vínculo com a universidade era tênue. Dez anos de furtos o haviam equipado com um belo laboratório próprio; sua renda era, em grande parte, composta de contratos dúbios com os cidadãos menos íntegros de Nova Crobuzon, cujas necessidades de uma ciência sofisticada o assombravam constantemente.

Mas a pesquisa de Isaac - que em todos esses anos não mudara em seus objetivos - não podia prosseguir no vácuo. Ele precisava publicar. Precisava debater. Precisava argumentar, ir a conferências - no papel do filho rebelde e errante. Ser um renegado tinha grandes vantagens. (MIÉVILLE, 2016, p.26)

Dessa forma, Isaac não se preocupa com questões morais quando o assunto é o avanço da sua pesquisa e se vale de medidas pouco usuais para alcançar seus objetivos científicos. Quando contratado por Yagharek para fazê-lo voar sem asas, Isaac aciona contatos no submundo da cidade para juntar exemplares de criaturas aladas raras, e acaba recebendo a lagarta colorida que, mais tarde, transforma-se em uma mariposa-libadora. Assim, Isaac torna-se responsável por liberar no mundo um grande mal, exatamente como Suvin diz ser um recurso narrativo tradicional nas obras de Wells.

Outra informação relevante desse sonho inaugural de Isaac está na disciplina da qual ele era professor: "Introdução às Ciências 
Materiais". Esse nome remete a um dos aspectos mais comumente associados à ficção científica: seu viés material, no sentido da manipulação de elementos fisicamente concretos - máquinas, naves espaciais e alterações corpóreas - em oposição às concepções espiritualistas ou metafísicas associadas à fantasia, como ressalta Roberts (2000, p.17). Dessa forma, Isaac é caracterizado como um cientista voltado ao estudo de fenômenos físicos, perfeitamente capaz de cumprir a função de validar cognitivamente para o leitor a realidade concreta do mundo ficcional, um dos fatores que Suvin elenca como necessários ao verdadeiro "novum": "a novidade tem que ser explicada de forma convincente em termos concretos e específicos, mesmo que imaginários, ou seja, em termos de tempo, espaço, agentes e totalidade social e cósmica de cada história" (SUVIN, 1979, p.80, tradução nossa). Parece possível também relacionar o termo "material" ao materialismo histórico ${ }^{5}$ e os pressupostos marxistas defendidos por Miéville, muito presentes na concepção do cenário.

5 Em Marxismo e crítica literária (2011), Terry Eagleton destaca duas passagens de livros de Marx e Engels que explicitam a noção de materialismo histórico. O primeiro, de $A$ ideologia alemã (1845-1866): “A produção de ideias, conceitos e consciência está, em primeiro lugar, diretamente ligada às relações materiais do homem, à linguagem da vida real. Conceber, pensar, as relações espirituais dos homens, aparecem aqui como a emanação direta do seu comportamento material [...] não partimos do que os homens dizem, imaginam ou concebem, nem dos homens como são descritos, imaginados ou concebidos, para chegar ao homem corpóreo; em vez disso, partimos do homem realmente ativo [...] A consciência não determina a vida: a vida determina a consciência". O segundo trecho é de Contribuição à crítica da economia política (1859): "Na produção social da sua vida, os homens entram em relações definidas que são indispensáveis e independentes da sua vontade, relações de produção que correspondem a um estágio de desenvolvimento definido das suas forças produtivas materiais. A soma total dessas relações de produção constitui a estrutura econômica da sociedade, a fundação real, sobre a qual se constrói a superestrutura jurídica e política e à qual correspondem formas definidas de consciência social, política e intelectual de maneira geral. Não é a consciência dos homens que determina o seu ser, mas ao contrário, seu ser social que determina sua consciência" (EAGLETON, 2011, p.16-17). 
Essa convenção narrativa representada por Isaac, a figura do protagonista-cientista, ao longo do romance começa a ganhar complexidade e trazer dúvidas quanto à sua rigidez em termos de lógica científica e cognitiva, aproximando-se da noção de "pseudociência". Ainda no primeiro capítulo, o narrador comenta que Vermishank, o antigo chefe de Isaac, é um "biotaumaturgo", mas não explica o que isso significa. Porém, pela simples referência à taumaturgia - uma forma de magia normalmente atribuída às divindades - associada ao diretor de um departamento da universidade, apresenta uma descontinuidade entre as concepções de ciência do mundo ficcional e do real, até então muito parecidas, o que gera um estranhamento. A partir daí, fica caracterizado que, em Nova Crobuzon, pesquisa científica e magia possuem algum tipo de relação próxima, que ainda não é explorada pelo texto. Trata-se de uma primeira amostra do entrelaçamento entre a fantasia e a ficção científica que será desenvolvido ao longo do romance.

Para Jameson, a magia é uma característica estrutural específica da fantasia - ao lado da abordagem ética binária entre o bem e o mal - que colabora decisivamente para diferenciá-la da ficção científica:

Se a ficção científica é a exploração de todas as restrições levantadas pela própria História - a teia de contrafinalidade e antidialética que a própria produção humana produziu - então a fantasia é o outro lado da moeda; uma celebração do poder criativo e da liberdade humanos que se torna idealista apenas em virtude da omissão precisamente dessas restrições materiais e históricas. A magia, então, pode ser lida não como um dispositivo facilitador do enredo (o que sem 
dúvida ela é no grande volume de produções medíocres de fantasia), mas como uma figura para o engrandecimento das potencialidades humanas que chegam ao limite, atualizando tudo o que está latente e virtual no organismo humano atrofiado do presente. (JAMESON, 2005, p.58, tradução nossa)

Em Estação Perdido, portanto, a magia pode ser encarada como um mecanismo que possibilita a reflexão sobre os limites das potencialidades humanas. Mais ainda, o fato da magia estar imbricada com a ciência em Bas-Lag, sendo justificada pela existência de partículas encantadas semelhantes ao próton, os "taumaturgons", e ser estudada em disciplinas específicas da universidade, permite que essa reflexão sobre potencialidades se expanda também para os limites do tecnológico, científico e social. De forma quase espelhada, essa mistura textual entre discurso científico e elementos mágicos por um lado aproxima a narrativa da ficção científica, por outro dota a história de uma aura sobrenatural, que a direciona à fantasia. O resultado é a forma híbrida característica do New Weird.

Além disso, a magia não aparece como um elemento acidental facilitador da trama que poderia ser substituído por outro análogo, mas como algo complexo, dotado de coerência e que tem relações com outras esferas dentro do mundo ficcional, influenciando sociedade, economia, política etc. A partir disso podemos retomar Jameson, na defesa de que Estação Perdido trata da questão da magia como as mais consequentes narrativas de fantasia o fazem:

A fantasia mais consequente nunca coloca a magia simplesmente a serviço de outros fins narrativos, mas propõe uma reflexão a respeito 
da magia em si mesma - sobre suas capacidades e propriedades existenciais, em um tipo de mapeamento figurativo da subjetividade ativa e produtiva em seu estado não-alienado. (JAMESON, 2005, p.66, tradução nossa)

Por fim, características do horror literário também estão presentes no romance. Suvin enquadra esse gênero na mesma categoria de fantasia, folclore, gótico, ghost story e weird, como um tipo de ficção comprometida com leis anticognitivas, portanto distante da ficção científica (SUVIN, 1979, p.8). Se, por um lado, há grande proximidade entre esses gêneros que narram fatos supostamente impossíveis - a grande maioria das histórias de fantasia possui pelo menos algum momento de tensão próxima ao horror, enquanto este se utiliza das criaturas mitológicas, efeitos mágicos e outras características do primeiro -, é possível traçar semelhanças também entre o horror e a ficção científica. Isso é evidente especialmente no que diz respeito ao seu desenvolvimento histórico, uma vez que ambos foram influenciados pelo romance gótico. Adam Roberts aponta que a partir do Gótico houve uma valorização do potencial da imaginação artística, o que foi fundamental para a construção de certas características que viriam a se tornar parte da concepção da ficção científica:

E foi com a implementação da Imaginação, a qual podemos ler para nosso propósito como "o criativo entrando nas possibilidades do fantástico, do desconhecido e do que não é o cotidiano", juntamente com o esplendor inspirador de "O Sublime" - que hoje está por trás do que às vezes é chamado de "Sentimento de Maravilhamento da 
ficção científica" - que se estabeleceu a estrutura artística dentro da qual todos os escritores de ficção científica atualmente trabalham. (ROBERTS, 2000, p.54, tradução nossa)

Além disso, diversos críticos, entre eles Jameson (2005) e Brian Aldiss (2005), situam origem da ficção científica na publicação de Frankenstein (1818), de Mary Shelley, um romance essencialmente gótico.

Estação Perdido traz de volta elementos góticos para o contexto da ficção científica e da fantasia. Diversas descrições de Nova Crobuzon remetem às convenções desse gênero, desde as vielas sombrias das cidades vitorianas dos romances do século XIX aos temas mais clássicos, como os castelos repletos de passagens labirínticas e tumbas. O edifício que dá nome à obra, a Estação Perdido, é uma das imagens mais claramente inspiradas pelo Gótico:

Um castelo industrial, eriçado com parapeitos aleatórios. A torre mais a oeste da estação era o Espigão, da milícia, elevada sobre as outras torretas, encolhendo-as, puxada em sete direções por linhas aéreas rígidas. Mas, apesar de toda sua altura, o Espigão era apenas um anexo da enorme estação. $\mathrm{O}$ arquiteto havia sido encarcerado, completamente louco, sete anos depois do término da construção da Estação Perdido. Diziam que era um herege, que tinha a intenção de construir seu próprio deus.

Cinco enormes bocas de tijolos se escancaravam para engolir cada uma das linhas de trem da cidade. Os trilhos se desenrolavam sobre os arcos como imensas línguas. Lojas, câmaras de tortura, oficinas, escritórios e espaços vazios, todos recheavam a barriga gorda do edifício, que parecia, visto de 
certo ângulo, sob certa luz, estar se segurando, apoiando seu peso no Espigão, preparando-se para dar um salto em direção ao imenso céu que ele invadia de modo tão casual. (MIÉVILLE, 2016, p.70)

A descrição externa remete por si só ao castelo gótico convencional, mas Miéville ainda completa a atmosfera com câmaras de tortura, um arquiteto insano e herético e localizando-a no bairro O Corvo, o mais gótico dos pássaros. Há, porém, diferenças fundamentais: os espaços tradicionais estão mesclados com escritórios e oficinas e são invadidos por trens suspensos. Isso mostra que não se trata verdadeiramente de um castelo do passado, mas de um castelo industrial, um castelofábrica da modernidade.

Nele o prefeito exerce sua autoridade quase totalitária como se fosse um verdadeiro aristocrata do passado, pois na república de Nova Crobuzon o voto é restrito a poucos e o governo se mantém o mesmo há muitos anos. Os soldados da milícia, que saem da torre adjacente, operam como se fossem espiões disfarçados de cidadãos comuns, surgindo das sombras para prender ou matar, parecendo mais criminosos do que oficiais da lei. Assim, em Estação Perdido, o elemento de horror gótico, muitas vezes associado a castelos em locais distantes, como Otranto ${ }^{6}$, ou a personagens estrangeiros, como Drácula, está presente no coração da cidade, controlando-a. Trata-se de um horror interno, próximo e constante, manifestando uma visão diferente do que era usual no Gótico clássico.

No que diz respeito à essa relação entre horror e crítica social, Darja Malcolm-Clarke aborda como essas questões aparecem 6 The Castle of Otranto (1764), de Horace Walpole, é considerado o primeiro romance gótico. Na história, o castelo está localizado no interior da Itália, na cidade de Otranto. 
no New Weird, e chega à conclusão de que o subgênero, nesse aspecto, não é análogo ao horror cósmico de Lovecraft ou do Weird tradicional, ou mesmo ao horror sobrenatural, no qual os momentos breves de medo ou angústia são fundamentais. A autora entende que o desconforto presente no New Weird está relacionado a uma estética grotesca que é parte da concepção dos mundos ficcionais como um todo e está justamente relacionada ao teor sócio-político dos textos.

O que é o grotesco? Por um lado, é um registro estético que incomoda. Considere gárgulas, Medusa, o monstro de Frankenstein, o alien nos filmes de mesmo nome. $\mathrm{O}$ sangue e as tripas de algum tipo de horror voltado a respingos sugerem a ansiedade a respeito da morte ou a tentativa de enfrentá-la. Mas o grotesco aponta para algo completamente diferente, algo mais sutil. É um desconforto que sugere que nossa maneira de classificar o mundo em partes conhecidas não é efetiva; é, no fim, confusão, porque as diferentes partes de algo não fazem sentido juntas. O grotesco demonstra que existem coisas para as quais não temos categorias e, portanto, que nossas formas de criar sentido são artificiais. (MALCOLM-CLARKE, 2008, p.339, tradução nossa)

Malcolm-Clarke enfatiza que o aspecto grotesco do New Weird aparece principalmente nas concepções das cidades e dos corpos físicos dos personagens, e que há uma relação direta entre os dois. Para ela, as cidades sombrias são manifestações de suas estruturas de poder, normalmente totalitárias, tirânicas, corruptas e malignas, as quais são responsáveis também por deixar marcas físicas grotescas na população. "Nesses textos, o grotesco aponta a artificialidade das estruturas sociais injustas" (MALCOLM-CLARKE, p.340, tradução nossa). 


\section{CONCLUSÃO}

O New Weird, portanto, promove uma diluição das fronteiras entre os gêneros da literatura fantástica, na medida em que características formais, convenções e temas tradicionais de ficção científica, fantasia e horror aparecem articuladas conjuntamente. O mundo ficcional dessas obras, alternativo ao real, é construído detalhadamente, enfatizando relações sociais, políticas e econômicas que remetem à nossa realidade, o que possibilita a reflexão acerca das relações do nosso próprio contexto sóciohistórico. Ao mesmo tempo, o romance permite ao leitor renderse ao conteúdo estranho, distanciando-se de analogias ou alegorias, pois a história e o cenário possuem coerência interna e uma infinidade de detalhes.

A respeito da pertinência da nomeação do subgênero, VanderMeer esclarece que, apesar de sua rejeição inicial - ele havia se manifestado contra criar uma nova categoria no fórum online de anos antes -, a existência do termo colaborou para que ele publicasse mais facilmente novos romances, e o mesmo aconteceu com outros autores, especialmente os estreantes. Para ele, contudo, ainda que o resultado tenha sido positivo, com o tempo a categorização passou a ter um significado essencialmente mercadológico - o que é um fato bastante comum em relação às categorias da literatura fantástica - distanciando-se das preocupações iniciais sobre a forma, o conteúdo e as influências do New Weird, o que fez com que até seus principais defensores Miéville, Harrison e Swainston - deixassem de lado as discussões sobre o subgênero. "A paixão por trás do esforço de Miéville 
garantiu que o termo perduraria, mesmo depois que ele passou a negá-lo, alegando que ele se tornara uma categoria de marketing e, portanto, não lhe interessava mais" (VANDERMEER, 2008, p.xiii, tradução nossa).

De fato, isso fez com que alguns autores continuassem sendo chamados de escritores New Weird mesmo quando suas experimentações já os levara a conjugar as características do subgênero com outras temáticas e convenções literárias, criando novos tipos de ficção, como é o caso, especialmente, de Miéville e VanderMeer.

\section{REFERÊNCIAS}

ALDISS, B.; WINGROVE, D (2005). "On the origin of species: Mary Shelley". In: GUNN, J.; CANDELARIA, M. Speculations on speculation. Lanham: Scarecrow Press, p.163-203.

BROOKER, M. Keith (2009). "The other side of history: fantasy, romance, horror and science fiction". In: CASERIO, R. L. The Cambridge companion to the twentiethcentury English novel. Cambridge: Cambridge University Press, p.251-266.

GORDON, Joan; MIÉVILLE, China (2003). "An interview with China -Miéville". Science Fiction Studies, 30(3), Nov. 355-373.

EAGLETON, Terry (2011) Marxismo e crítica literária. São Paulo: Editora Unesp. JAMESON, Fredric (2005). Archaeologies of the future - the desire called utopia and other science fictions. London: Verso.

LOVECRAFT, Howard Phillips (2012). O chamado de Cthulhu. São Paulo: Hedra. MALCOLM-CLARKE, Darja (2008). "Tracking phantoms". In: VANDERMEER, J.; VANDERMEER, A. The New Weird. São Francisco: Tachyon. p.337-343.

MIÉVILLE, China (2003). "Long live the New Weird". The 3rd alternative, Cambs, 35, Jul. 3.

(2009). "Weird fiction". In: BOULD, M. et al. The Routledge companion to science fiction. Nova lorque: Routledge. p.510-515. 
(2016). Estação Perdido. São Paulo: Boitempo.

MOYLAN, T (2000). Scraps of the untainted sky - Science Fiction, Utopia, Dystopia. Oxford: Westview Press.

ROBERTS, Adam (2000). Science Fiction. London: Routledge.

THE NEW WEIRD (TNW). In http://www.kathryncramer.com/ kathryn_cramer/ the-new-weird-p-1.html Acesso em 5.Mai.2017.

SUVIN, Darko (1979). Metamorphoses of Science Fiction. London: Yale University Press.

VANDERMEER, J. (2008). "The New Weird: "It's alive?"” In: VANDERMEER, A.; . The New Weird. São Francisco: Tachyon, p.ix-xviii. 